\section{GEOLOGIC EVOLUTION OF IRON MOUNTAIN, CENTRAL MOJAVE DESERT, CALIFORNIA}

Stefan S. Boettcher ${ }^{1}$

Department of Geology, University of North Carolina at Chapel Hill

\author{
J. Douglas Walker \\ Department of Geology \\ University of Kansas \\ Lawrence, Kansas
}

Abstract. Geologic mapping, structural analysis, petrologic study, and U-Pb geochronology at Iron Mountain, $20 \mathrm{~km}$ southwest of Barstow, California, place important constraints on the paleogeographic affinities of metasedimentary rocks in the area and provide new data to test Mesozoic and Cenozoic tectonic models for the central Mojave Desert. Rocks present at Iron Mountain include: Precambrian(?) and/or lower Paleozoic(?) miogeoclinal rocks, Middle Jurassic tonalite, Middle Jurassic Hodge volcanic series, Late Jurassic homblende diorite, Cretaceous(?) peraluminous granite, and Cretaceous(?) granodiorite prophyry. Two phases of ductile deformation are present at Iron Mountain. The first phase, which penetratively deforms the miogeoclinal rocks, tonalite, and Hodge volcanic series, developed under amphibolite and greenschist facies metamorphic conditions. Fabric development in the Hodge volcanic series preceded emplacement of $151 \pm 11$ Ma granite. The second fabric deforms peraluminous granite and Late Jurassic homblende diorite as well, and consists of spaced mylonitic shear zones. The shear zones predate emplacement of Late Cretaceous dikes $(83 \pm 1 \mathrm{Ma})$. The presence of probable miogeoclinal strata indicates that the boundary between allochthonous eugeoclinal rocks and parautochthonous miogeoclinal/cratonal rocks must lie north of Iron Mountain. The older amphibolite facies metamorphism and contractile deformation at Iron Mountain are interpreted to be part of a belt of Middle to Late Jurassic age deformation that runs northeastward through the Mojave Desert and forms the southern continuation of the east Sierran contractile belt. Newly recognized subvertical mylonitic shear zones of Cretaceous age at Iron Mountain have not been documented elsewhere in the central Mojave Desert. No significant Tertiary ductile deformation fabrics are present at Iron Mountain.

\section{INTRODUCTION}

Much of the geologic history of the central Mojave Desert in southern California is recorded in mountain ranges separated by large expanses of alluvium. Each range contains important information, but correlation of structural, lithologic, and geochronologic data from range to range has proven difficult. In recent years, detailed mapping coupled with U-Pb geochronology has shown that structural elements exposed

\footnotetext{
${ }^{1}$ Now at Department of Geological Sciences, University of Texas at Austin.

Copyright 1993 by the American Geophysical Union.

Paper number $92 \mathrm{TC} 02423$. $0278-7407 / 93 / 92 \mathrm{TC}-02423 \$ 10.00$
}

within the ranges are regionally extensive and can be accounted for in tectonic models for the Mojave Desert. New geologic mapping and U-Pb geochronology at Iron Mountain, located $20 \mathrm{~km}$ southwest of Barstow, California place constraints on the location of regional structures in the central Mojave Desert (Figures 1 and 2). Iron Mountain provides an excellent locality to address Mesozoic tectonic models that predict contraction or extension for the Mojave Desert and eastern Sierra Nevada owing to its proximity to ranges where evidence for current models has been obtained. Specifically, ignimbrite and quartz sandstone of the Sidewinder volcanic series, exposed in the Sidewinder Mountains $\sim 20 \mathrm{~km}$ southeast of Iron Mountain, has been cited as evidence for the extensional nature of the early Mesozoic arc in the Mojave Desert [Busby-Spera, 1988]. In contrast, Late Jurassic contractile deformation has been documented in the Cronese Hills [Walker et al., 1990a], located $\sim 50 \mathrm{~km}$ to the northeast of Iron Mountain and in the White-Inyo Mountains and Argus Range north of the Garlock fault in eastern California [Dunne et al., 1978; Dunne, 1986]. Specific geologic problems at Iron Mountain that bear on this question include the timing and tectonic significance of an inferred kilometer-scale, isoclinal fold and meter- to centimeter-scale, tight- to isoclinal-type folds.

In addition, evaluation of rock types present in a $1 \mathrm{~km}$ wide exposure of metasedimentary rocks in the northem part of Iron Mountain provides new data on the location of the miogeoclinal/eugeoclinal boundary in the central Mojave Desert. The correlation of metasedimentary rocks at Iron Mountain with Late Precambrian to lower Paleozoic sedimentary rocks of the Cordilleran miogeocline and its bearing on the location of proposed regional structures will be addressed in this paper.

Last, the postition of Tertiary detachment faults relative to numerous ranges in the central Mojave Desert remains unclear. Iron Mountain, located $\sim 15 \mathrm{~km}$ southwest of exposures of known footwall rocks in the Hinkley Hills has been described as possibly lying in the footwall of the central Mojave metamorphic core complex [Walker et al., 1990b]. The nature and tectonic significance of structures at Iron Mountain are discussed in this paper in the context of recently proposed models for the magnitude and significance of Tertiary extension in the Mojave Desert.

\section{LITHOLOGIC DESCRIPTIONS}

Previous geologic investigations at Iron Mountain include work by Miller [1944], who discussed lithologies and possible regional correlations, and by Bowen [1954], who published a 1:125,000 geologic map of the Barstow $30^{\prime}$ quadrangle. Dibblee [1960] published a geologic map of the Barstow 15' quadrangle, mapped Iron Mountain [Dibblee, 1967] at a scale of $1: 62,500$, and presented the first description of many of the rock types at Iron Mountain.

Detailed geologic mapping at 1:12,000 of the entire range, undertaken by S.S. Boettcher in the Fall of 1989, has led to the refinement of earlier descriptions, documentation of field relations, and discovery of previously unrecognized structural complexities (Figure 3; Boettcher, [1990a, b]; Boettcher and Walker, [1990]). To better define the chronology of intrusion/extrusion, metamorphism and deformation, $\mathrm{U}-\mathrm{Pb}$ analysis of zircon and monazite was done on several of the igneous units. Results are given in Table 1 and presented in Figure 4. We analyzed samples of the Hodge volcanic series (sample QBmv) and postkinematic granite (WCG) from the southern area, and gneissic tonalite (IM-101) and postkinematic muscovite garnet granite dikes (mgg-1) from the northern area. This new U-Pb geochronology and 


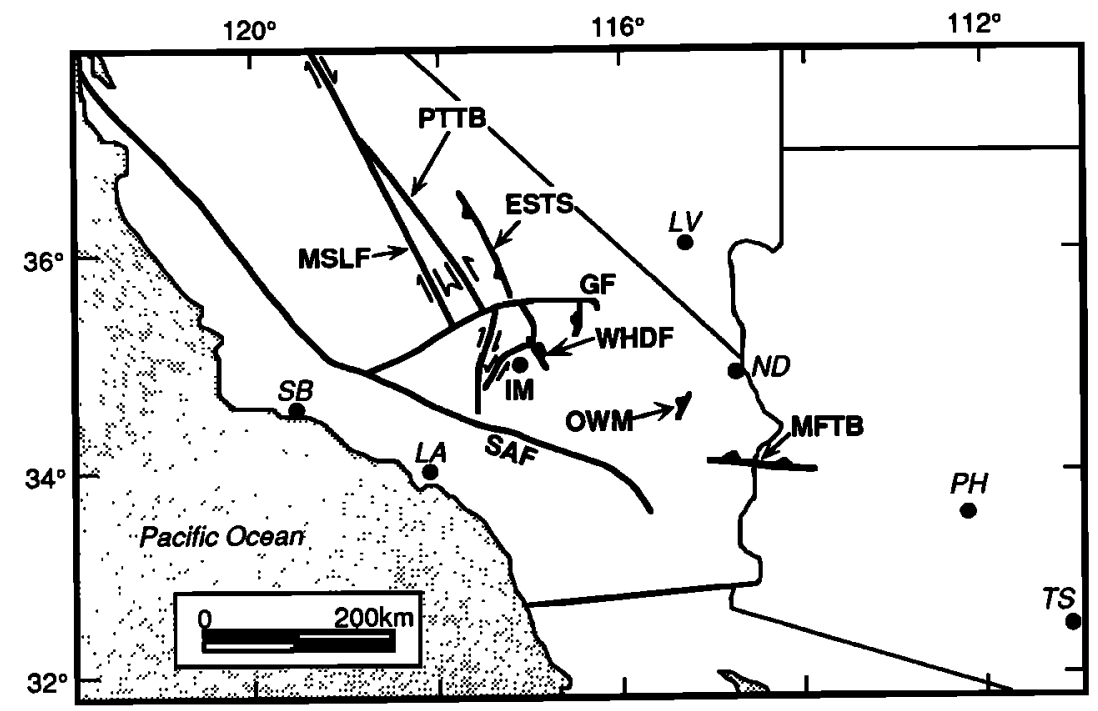

Fig. 1. Map of the southwestem United States showing regional structures and the location of Iron Mountain (IM). The Permo-Triassic truncation boundary (PTTB), east Sierran thrust system (ESTS), Mojave-Snow Lake fault (MSLF), and Waterman Hills detachment fault (WHDF) are of particular interest to this study. Other important regional structures and localities include the San Andreas fault (SAF), Garlock fault (GF), Old Woman Mountains (OWM) and the Maria fold and thrust belt (MFTB). Abbreviations for geographic markers are: LV, Las Vegas; ND, Needles; PH, Phoenix; TS, Tucson; LA, Los Angeles; and SB, Santa Barbara. lithologic comparison with similar rock types elsewhere in the Mojave Desert are the basis of age constraints for units in this study. Table 2 is a summary of age constraints and lithologies for the different rock types at Iron Mountain.

\section{Metasedimentary Sequence}

The northern area of Iron Mountain consists of light colored, low hills dominated by coarsely crystalline dolomitic marble that is massive to finely laminated. A distinct, micaceous quartzite unit, up to $50 \mathrm{~m}$ thick, forms a prominent marker. It contains abundant, closely spaced, dark laminations of biotite, magnetite and other heavy minerals and is commingled with isoclinally folded quartz-feldspar injection gneiss. The laminations in the quartzite and the compositional layering in the marble are probably primary bedding structures that have been transposed during deformation and metamorphism. Four other vitreous quartzite units, generally less than $5 \mathrm{~m}$ thick, occur as 25 to $500 \mathrm{~m}$ long pods along strike and locally contain a biotite lineation that plunges shallowly to the northeast. Dark-weathering, banded calc-silicate gneiss and muscovite-biotite schist occur locally and are discontinuous along strike. Sedimentary structures are not recognized and have presumably been obliterated by deformation.

The local occurrence of fibrolitic sillimanite in micaceous quartzite, prismatic sillimanite and garnet in biotite-muscovite schist, hornblende and plagioclase in calc-silicate gneiss, and more widespread occurrences of diopside, forsterite and enstatite in dolomitic marble indicate amphibolite facies metamorphism in the metasedimentary sequence [Winkler, 1979]. In the micaceous quartzite, fibrolite occurs in small mats intergrown with, and possibly forming from, 1 to $2 \mathrm{~mm}$ long packets of muscovite in a rock otherwise dominated by quartz and 2 to $5 \mathrm{~mm}$ thick layers of biotite. The equilibrium assemblage in the micaceous quartzite is quartz + biotite \pm muscovite \pm sillimanite.
Biotite-muscovite schist contains rare large (up to $1 \mathrm{~cm}$ ), subhedral garnet crystals and both euhedral-prismatic and anhedral-fibrolitic sillimanite at six different localities in the northern area. The equilibrium assemblage garnet + sillimanite + quartz + plagioclase + biotite + muscovite occurs in at least two $5 \mathrm{~m}^{2}$ areas of weathered biotite-muscovite schist that are separated by several kilometers. Sillimanite and biotite are locally kinked and folded.

Calc-silicate gneiss is a distinctly banded rock with alternating 1 to $20 \mathrm{~mm}$ thick, light plagioclase-quartz-rich and dark hornblende-rich layers, interrupted by pelitic layers rich in biotite and sillimanite. The equilibrium assemblage hornblende + plagioclase + diopside + quartz is commonly retrograded to epidote + albite + sphene + diopside + quartz.

In three thin sections of dolomitic marble, forsterite and enstatite occur in equal proportions as anhedral crystals that are round in thin section. Diopside occurs in greater proportions and is subhedral to anhedral. The marble is highly recrystallized, with dolomite crystals commonly as large as 1 $\mathrm{cm}$. The equilibrium assemblages in the marble are dolomite + diopside + forsterite + enstatite \pm phlogopite \pm calcite \pm quartz.

The presence of chlorite, serpentine, epidote and albite in rocks containing amphibolite facies assemblages indicates the instability of the higher grade assemblage. Secondary alteration of forsterite to serpentine is common. In addition, local 5 to $15 \mathrm{~m}^{2}$ pods of very coarse-grained gamet-quartzepidote hornfels and black-weathering calc-silicate rock occur in areas where granitic rocks and marble are commingled. These rocks lack the high-temperature assemblage of the metasedimentary sequence and represent skarn mineralization or metasomatism associated with igneous events that postdate the amphibolite facies metamorphism of the metasedimentary sequence.

Miller [1944] included the metasedimentary sequence with the Hinkley Valley complex, which he proposed is middle 


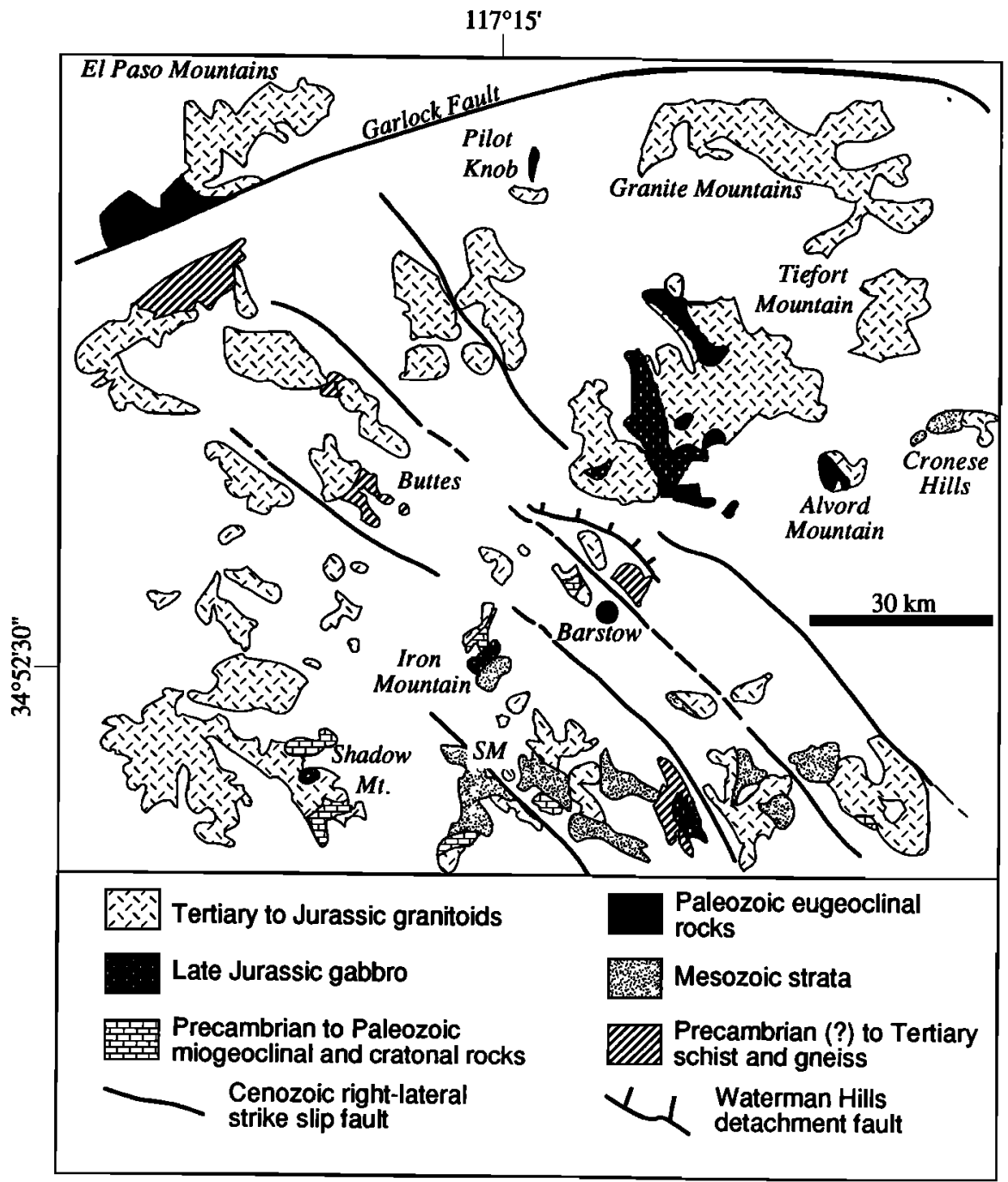

Fig. 2. Simplified geologic map of the central Mojave Desert showing the distribution of preTertiary rocks and major Cenozoic faults. The
Cronese Hills, Shadow Mountains, Sidewinder Mountain (SM), and Iron Mountain are the regional focus of this study [after Jennings, 1977].
Paleozoic or older based on regional lithologic and crosscutting relationships. Bowen [1954] correlated the metasedimentary sequence with the Oro Grande series of the Victorville area and assigned it a Carboniferous age based on two poorly preserved brachiopods in the Shadow Mountains. Dibblee [1967] stated that the metasedimentary sequence is unlike rocks of the Oro Grande series and grouped the sequence at Iron Mountain with the Waterman Gneiss and inferred a Precambrian age.

The large proportion of marble and quartzite relative to calcsilicate rocks and pelitic schists at Iron Mountain suggests that the metasedimentary sequence was deposited in a miogeoclinal or craton margin setting [Boettcher, 1990b]. On the basis of comparison with rocks described by Hazzard [1937], Stewart [1970], and Stewart and Poole [1975], we correlate the metasedimentary sequence with the Cordilleran miogeoclinal rocks of the Late Proterozoic Noonday Dolomite and lower part of the Johnnie Formation. The Noonday Dolomite-Johnnie Formation interval contains massive dolomite, interlayered thin clean quartzites, laminated dolomite, and calc-silicate rocks overlain by finely laminated thick quartzite [Stewart, 1970].

Kiser [1981] correlated a metasedimentary sequence in the Hinkley Hills, located $15 \mathrm{~km}$ northeast of Iron Mountain, with the Lower Cambrian Wood Canyon Formation. The Wood Canyon Formation is a predominantly clastic unit with lesser amounts of dolomite and limestone that is grouped in the Death Valley facies of the Cordilleran miogeocline [Stewart, 1970]. The large proportion of carbonate in the Iron Mountain sequence makes correlation with the Wood Canyon Formation unlikely. Miller [1981a, b] identified a pre-Wood Canyon Formation sequence of dolomite with thin layers of calcsilicate and quartzite at Quartzite Mountain, north of Victorville (Figure 2). She had difficulty finding a stratigraphic match for this sequence but suggested a late Precambrian age based on gross lithologic comparison with units in the San Bernardino Mountains. The Iron Mountain sequence exhibits some similarities to the upper part of the Green Spot Formation and the Delamar Mountain Formation of the Big Bear Group in the San Bernardino Mountains 


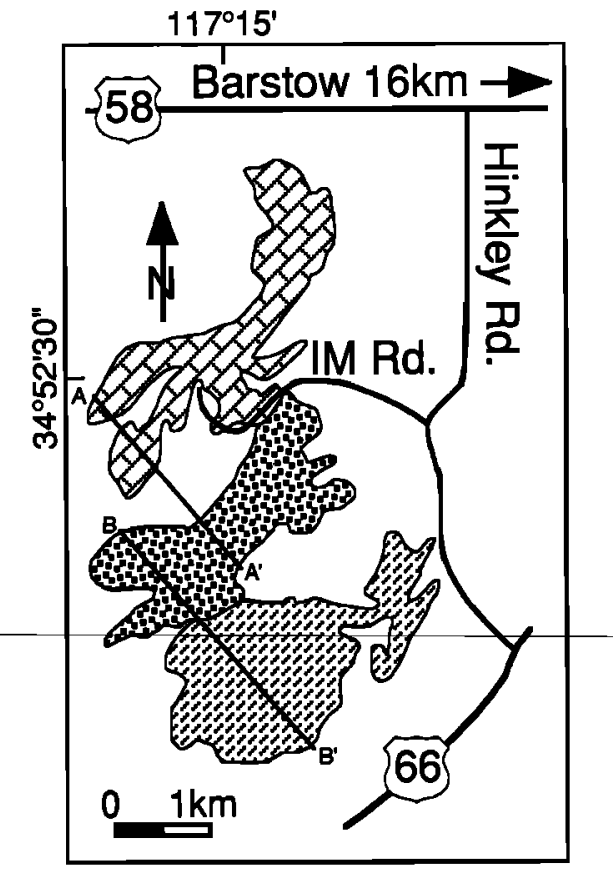

Fig. 3. Simplified geologic map showing the subdivision of Iron Mountain into a northern area of metasedimentary and plutonic rocks, a central area of mainly homblende diorite, and a southem area consisting of the Hodge volcanic series. Cross section lines A-A' and B-B' shown for Figure 9 (compiled from Dibblee, [1967] and Boettcher, [1990b]).

[Cameron, 1982], but the quartzites at Iron Mountain do not contain abundant feldspar grains that are characteristic of the quartzite units in the Green Spot-Delamar Mountain interval. There are few similarities between the metasedimentary sequence at Iron Mountain and younger sections of the Cordilleran miogeocline or eugeocline. In particular, the Middle Cambrian Bonanza King Formation and the Upper Cambrian Nopah Formation, exposed in Death Valley, California, are both predominantly dolomite [Stewart, 1970], but lack the distinctive, thin layers of orthoquartzite and thicker layer of micaceous quartzite found at Iron Mountain.

\section{Hodge Volcanic Series}

The Hodge volcanic series is exposed approximately $3 \mathrm{~km}$ to the south of the metasedimentary sequence in low, variably colored hills that are dissected by numerous gullies. The dominant rock type is a dark weathering, porphyritic quartzplagioclase-biotite metavolcanic rock with a foliation that weakens to the southeast. The foliation is generally parallel to the contacts between compositional layers but locally crosses the layering at low angles. The compositional layering is most obvious in the hills just north of the Mojave River where 3 to $10 \mathrm{~m}$ thick subvertical light tan, pink, and dark brown to black layers produce a striped pattern on the low hills. The quartzplagioclase-biotite metavolcanic rock is interlayered with a fine-grained, white to light tan, strongly foliated $(0.1$ to $1 \mathrm{~cm}$ spacing of foliation planes) muscovite-sericite schist with both quartz- and chlorite-rich layers and, locally abundant elongate quartz pebbles. Additionally, distinct, resistant, desertvarnished quartzite boudins occur within the muscovitesericite schist unit. The quartzite is thick-bedded (up to $1 \mathrm{~m}$ ), contains greater than $95 \%$ quartz and is commonly broken into angular fragments cemented by hematite or limonite at the ends of the boudins.

No minerals indicative of temperatures higher than greenschist facies were observed in the Hodge volcanic series. The assemblage biotite + quartz + muscovite + clinozoisite + plagioclase is typical of the metavolcanic rocks of the Hodge volcanic series. Plagioclase crystals commonly show alteration to sericite and, less commonly, calcite.

Additionally, the muscovite-sericite schist unit of the Hodge volcanic series appears to have undergone an episode of alteration that produced fine-grained mica, characteristic light tan color, and friable nature.

The proximity of the Hodge volcanic series to the Sidewinder volcanic series and similarities in lithologies (J. D. Walker and E. Schermer, personal communication, 1990) between these units suggest that these series are correlative. The Sidewinder volcanic series (U-Pb age on zircon from basal unit $\sim 171 \mathrm{Ma}$, Graubard et al. [1988]) is a dominantly pyroclastic unit with interbedded quartz-rich volcanogenic sandstones. Compositions are mainly rhyolitic to dacitic, with less abundant exposures of andesite [Bowen, 1954]. The Sidewinder volcanic series and the Hodge volcanic series are separated by granitic plutons that intrude both series. The closest outcrops of the two series are approximately $10 \mathrm{~km}$ apart.

A zircon age from foliated quartz-plagioclase-biotite metavolcanic rock (sample QBmv) strongly supports correlation of the Hodge and Sidewinder volcanic series. Three bulk fractions from this sample yield a lower intercept age of $160 \mathrm{Ma}$. Two air-abraded fractions give an older age of $164 \mathrm{Ma}$ indicating that the zircons have suffered some $\mathrm{Pb}$ loss (Figure 4). Results from other volcanic rocks in the region [e.g., Busby-Spera et al., 1990] and similar volcanic rocks from the southern Inyo Mountains [Dunne and Walker, 1991; and unpublished data, 1991] indicate that minor $\mathrm{Pb}$ loss is typical of zircons in these sequences. Given the degree of $\mathrm{Pb}$ loss exhibited by these other volcanic sequences, we interpret $164 \mathrm{Ma}$ to be a minimum age and consider it probable that the true age may be $170 \mathrm{Ma}$ or very slightly older.

\section{Granite of Wild Crossing}

At the extreme southern end of the area, just north of the Mojave River, an isotropic, pink-stained, equigranular granite locally contains xenoliths of foliated quartz-plagioclase-biotite metavolcanic rock. Zircons from this post-kinematic granite (sample WCG) show the combined affects of Pb-loss and inherited xenocrystic zircon. We have air abraded a fraction of the more magnetic zircon. The abraded fraction gives older $\mathrm{U}-\mathrm{Pb}$ and $\mathrm{Pb} / \mathrm{Pb}$ ages than the corresponding unabraded fraction (Figure 4). This fraction and two nonmagnetic fractions lie on a chord giving a lower intercept age of $151 \pm$ $11 \mathrm{Ma}$ (Figure 4). We interpret this as a minimum crystallization age, but consider this not to be significantly younger than the true age of the rock.

\section{Gneissic Tonalite}

The metasedimentary sequence in the northem part of the area is intruded by several igneous bodies. The oldest igneous phase was pervasively deformed along with the host sediments to a schistose to gneissic tonalite. The equilibrium mineral assemblage in the gneissic tonalite is plagioclase + quartz + biotite \pm muscovite. Plagioclase crystals are locally retrograded to epidote and calcite. Mineral assemblages characteristic of a particular metamorphic facies were not observed in the gneissic tonalite. Analyses of zircon fractions from the gneissic tonalite (sample IM-101) did not yield easily 


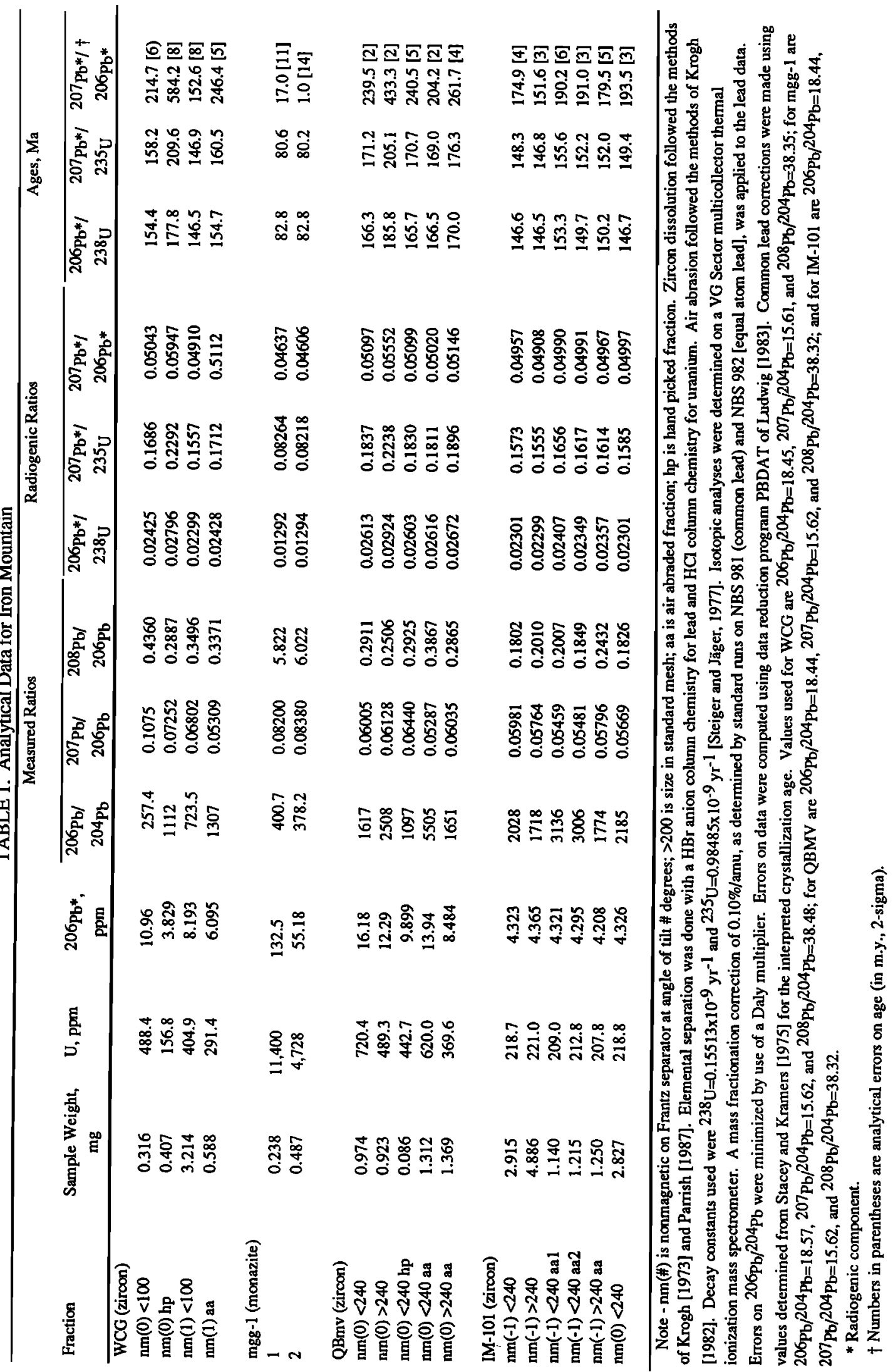



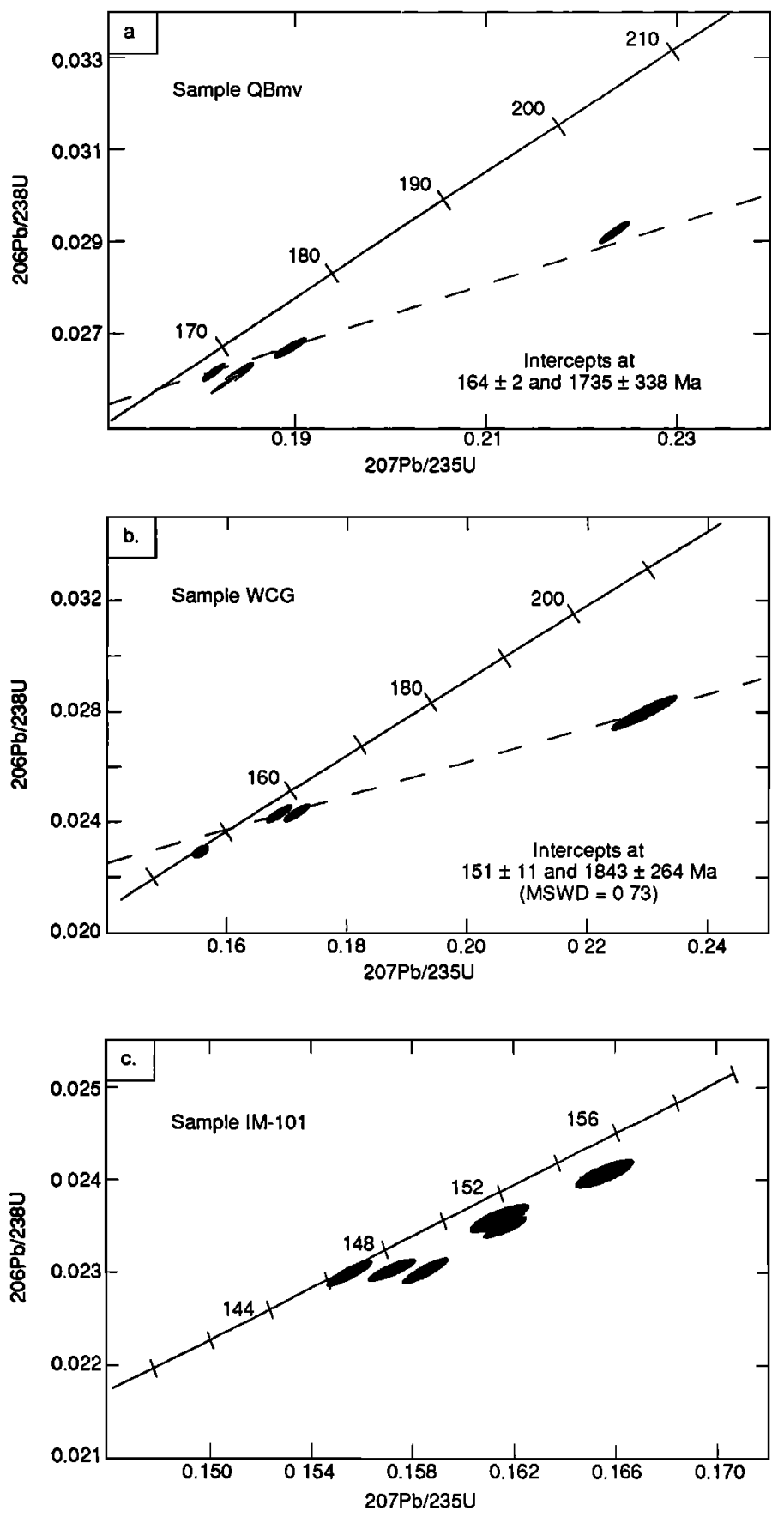

Fig. 4. Concordia diagrams for U-Pb analyses. (a) Air-abraded fraction from sample QBmv yields a lower intercept age of $164 \pm 2$ Ma. Results from other volcanic rocks in the region [e.g., BusbySpera et al., 1990] and similar volcanic rocks from the southern Inyo Mountains [Dunne and Walker, 1991; also unpublished data, 1991] typically exhibit $\mathrm{Pb}$-loss. Given the degree of $\mathrm{Pb}$-loss exhibited by these other volcanic sequences, we interpret 164 Ma to be a minimum age and consider it likely that the true age is 165 to $170 \mathrm{Ma}$, (b) For sample WCG, four fractions are plotted but only three are used in the regression: data for $n m(0)$ and $n m(1) A A$ fractions. Air abrasion of the nm(1) fraction drove the point toward the regression line of the $\mathrm{nm}(0)$ data. From this we interpret the sample to have undergone $\mathrm{Pb}$ loss and to contain an inherited xenocrystic zircon component. The age of $151 \pm$ $11 \mathrm{Ma}$ therefore represents a minimum age for this sample, (c) Bulk fractions from sample IM-101 cluster at about 148 to $150 \mathrm{Ma}$. Air-abraded fractions plot at older $\mathrm{U}-\mathrm{Pb}$ ages, thus indicating $\mathrm{Pb}$ loss. Our preferred interpretation is that the sample is $170 \mathrm{Ma}$, the age of similar granitic rocks in the region (see discussion) and has an inherited component and has suffered $\mathrm{Pb}$ loss. 
TABLE 2. Summary of Age Constraints for Rocks Present at Iron Mountain

\begin{tabular}{|c|c|c|}
\hline Iron Mountain & Regional Occurrence & Age Constraints \\
\hline \multicolumn{3}{|c|}{ Northern Area } \\
\hline Peraluminous granite & $\begin{array}{l}\text { Fremont Peak and The Buttes [J.S. } \\
\text { Miller et al., 1992], } \\
\text { Old Woman Mountains and Piute } \\
\text { Mountains [C.F. Miller et al., 1982] }\end{array}$ & $\begin{array}{l}\text { Younger than Mesozoic } 148 \mathrm{Ma}(?) \\
\text { gabbro/diorite and older than } 83 \pm 1 \mathrm{Ma} \\
\text { undeformed dikes at Iron Mountain; } \\
\text { Late Cretaceous in eastern Mojave Desert; } \\
\text { Late Cretaceous biotite monzogranite in } \\
\text { Fry and Ord Mountains [Karish et al., } \\
\text { 1987] }\end{array}$ \\
\hline Gneissic tonalite & $\begin{array}{l}\text { Westem San Bemardino Mountains } \\
\text { [Dibblee, 1967], } \\
\text { Lane Mountain [McCulloh, 1952] }\end{array}$ & $\begin{array}{l}\text { Probably Jurassic, U/Pb } 152-190 \mathrm{Ma} \text {; } \\
\text { older than } 148 \mathrm{Ma}(?) \text { gabbro/diorite and } \\
\text { younger than metsedimentary sequence at } \\
\text { Iron Mountain }\end{array}$ \\
\hline $\begin{array}{l}\text { Metasedimentary } \\
\text { sequence }\end{array}$ & $\begin{array}{l}\text { Miogeoclinal facies; Similar facies at } \\
\text { Quartzite Mountain and Sidewinder } \\
\text { Mountain, [Miller, 1981], Hinkley } \\
\text { Hills [Kiser,1981], Newberry } \\
\text { Mountains, [Glazner et al., 1988] and } \\
\text { San Bernardino Mountains [Cameron, } \\
\text { 1982] }\end{array}$ & $\begin{array}{l}\text { Similar in lithology to Late Precambrian } \\
\text { Noonday Dolomite and Johnnie } \\
\text { Formation in Death Valley area and Late } \\
\text { Precambrian to early Paleozoic } \\
\text { metasedimentary rocks present in the } \\
\text { Victorville area [Miller, 1981a, b] }\end{array}$ \\
\hline Granodionite porphyry & Alvord Mountain & $\begin{array}{l}82 \mathrm{Ma} \text { at Alvord Mountain [Walker et al., } \\
\text { 1990c]; }\end{array}$ \\
\hline Hornblende diorite & $\begin{array}{l}\text { Shadow Mountains, Goldstone, } \\
\text { Coolgardie Camp, and Snow Lake } \\
\text { pendant [Sierra Nevada] }\end{array}$ & $\begin{array}{l}148 \mathrm{Ma} \text { U/Pb zircon age from Shadow } \\
\text { Mountains [Martin et al., 1990], Snow } \\
\text { Lake pendant [Lahren, et al., 1990]; } \\
148 \mathrm{Ma} \text { Ar/Ar age from Goldstone } \\
\text { [Miller and Sutter, 1982] }\end{array}$ \\
\hline Granite & Southern Area & $\begin{array}{l}151 \pm 11 \mathrm{Ma} U / \mathrm{Pb} \text { zircon at Iron } \\
\text { Mountain; } \\
154 \pm 1 \mathrm{Ma} \mathrm{U} / \mathrm{Pb} \text { zircon in the Cronese } \\
\text { Hills [Walker et al., 1990a] }\end{array}$ \\
\hline Hodge volcanic series & Sidewinder volcanic series & $\begin{array}{l}\text { Jurassic, U/Pb minimum age } \sim 164 \mathrm{Ma} \text {; } \\
\mathrm{U} / \mathrm{Pb} \text { zircon age of } 171 \mathrm{Ma} \text { for } \\
\text { Sidewinder volcanic series [Graubard, } \\
1988 \text { ] }\end{array}$ \\
\hline
\end{tabular}

interpretable results (Figure 4). Bulk fractions cluster at about 148 to $150 \mathrm{Ma}$. Air-abraded fractions plot at older U-Pb ages, thus indicating $\mathrm{Pb}$ loss. Unfortunately, air abrasion did not create any sort of discordia array, and we interpret this sample to have undergone extensive $\mathrm{Pb}$ loss (possibly combined with inherited xenocrystic zircon). This is not unexpected. First, the sample collected, although as fresh as could be found, was somewhat weathered and friable (a pervasive feature of this unit). Second, the extreme deformation and metamorphism suffered by this unit probably opened the zircons to $\mathrm{Pb}$ loss. We offer two interpretations for these data. First, if we assume that the sample contains an inherited component, then the minimum age of this sample is $152 \mathrm{Ma}$. This is the approximate age of a chord between the oldest fraction and an assumed $1800 \mathrm{Ma}$ upper intercept (typical inheritance age for granites in this region). Alternatively, if only $\mathrm{Pb}$ loss has occurred, then the sample is probably about $190 \mathrm{Ma}$. This is the average of the $\mathrm{Pb} / \mathrm{Pb}$ ages of three older fractions. Our preferred interpretation is that the sample is about $170 \mathrm{Ma}$, the age of similar granitic rocks in the region (see discussion below) and has both suffered Pb loss and contains an inherited component.

\section{Hornblende Diorite}

A stock-sized body of homblende diorite is present in the central part of Iron Mountain and commonly has a color index close to 65. It is composed mainly of homblende and plagioclase with lesser amounts of sphene, augite, and opaque minerals, has a poikilitic texture, and contains four mappable (at $1: 12,000$ ) $0.1 \mathrm{~m}$ to $10 \mathrm{~m}$ wide shear zones. Gabbro, with a color index of 80 or higher, occurs as small bodies within the 
diorite. Medium- to very coarse-grained gabbro dikes and xenoliths are locally present. Greenschist facies metamorphism associated with mylonitic shear zones in the hornblende diorite is characterized by the instability of homblende and the presence of actinolite, clinozoisite/zoisite, chlorite, and albite.

The age of the hornblende diorite complex is inferred by correlations of intrusive relations to adjacent areas. Bowen [1954] stated that small intrusions of hornblende diorite cut the Sidewinder volcanic series across the Mojave River, $30 \mathrm{~km}$ southeast of Iron Mountain. No intrusions of gabbro or diorite were observed in the southern metavolcanic rocks at Iron Mountain, however. Both U-Pb zircon ages of similar gabbros in the Shadow Mountains [Martin and Walker, 1989] and ${ }^{40} \mathrm{Ar}-{ }^{39} \mathrm{Ar}$ ages of similar gabbros from the Goldstone area [Miller and Sutter, 1982] $40 \mathrm{~km}$ northeast of Iron Mountain are $\sim 148 \mathrm{Ma}$. These data currently provide the best correlation for the age of the gabbro/diorite complex in the central part of Iron Mountain.

\section{Peraluminous Granite}

Two phases of variably deformed peraluminous granite are present in the northern and central areas of Iron Mountain. Dikes of sheared biotite granite with local occurrences of muscovite and a leucocratic (color index $<5$ ) biotite granite that contains pods of abundant gamet and muscovite intrude the hornblende diorite body, gneissic tonalite, and metasedimentary sequence. Metamorphism of these phases in shear zones is characterized by the breakdown of plagioclase to form albite, calcite and epidote.

The apparent lack of plutonism during the interval 147-125 Ma [Chen and Moore, 1982] followed by Early to Late Cretaceous granitic plutonism in the central Mojave Desert and Sierra Nevada suggests that sheared biotite granite dikes in the diorite body and sheared peraluminous granite in the northern area may be significantly younger than $150 \mathrm{Ma}$. In particular, $\sim 98$ Ma synkinematic peraluminous granite is present at Fremont Peak in the NW Mojave Desert (U-Pb zircon, J.S. Miller et al., [1992]) and Late Cretaceous biotite monzogranite is present east of Victorville [Karish et al., 1987].

\section{Muscovite-Garnet Granite}

Undeformed, 2 to $20 \mathrm{~m}$ thick, northwest trending dikes of coarse-grained muscovite-garnet granite crosscut mylonitic fabrics in the gneissic tonalite. U-Pb results on monazite from these dikes consist of two reversely discordant fractions that yielded nearly identical analyses (Table 1). Following the reasoning outlined by Parrish [1990], we interpret the age of this sample to correspond to the average of the ${ }^{207} \mathrm{~Pb} / 235_{U}$ ages. Thus, this sample is dated at $83 \pm 1 \mathrm{Ma}$.

\section{Granodiorite Porphyry}

An undeformed granodiorite porphyry separates the Hodge volcanic series from the homblende diorite body. This unit is characterized by large ( 2 to $4 \mathrm{~cm}$ long), randomly oriented $\mathrm{K}$ feldspar megacrysts in a matrix of medium-grained plagioclase, biotite, and quartz. Granodiorite porphyry exposed to the north of the Hodge volcanic series is not mylonitic, nor is the southern margin of the homblende diorite complex of the central area, suggesting that the granodiorite porphyry was intruded along a now obliterated contact between the Hodge volcanic series and the homblende diorite body. Granodiorite porphyry dikes at Alvord Mountain (82 Ma U-Pb zircon; Walker et al., [1990c]), located $30 \mathrm{~km}$ east of
Barstow, are similar in mineralogy and texture to the granodiorite porphyry body at Iron Mountain.

\section{Felsite Dikes}

Light gray, 1 to $3 \mathrm{~m}$ wide, fine-grained dikes crosscut all deformation fabrics and previously mentioned rock types. These dikes locally contain complex refolded fold patterns that likely formed during emplacement. Similar felsite dikes are present to the north and east at Fremont Peak, Hinkley Hills, and Mitchel Range. Dikes in these areas are Early Miocene ( 23 Ma; Walker et al. [1990b] and Walker and Martin, unpublished data, [1991]), which wc interpret to be the age of dikes at Iron Mountain.

\section{STRUCTURE}

Four major structural elements are present at Iron Mountain: (1) gneissic fabric in the tonalite and schistose fabric in the Hodge volcanic series; (2) close- to isoclinal-type folds involving the metasedimentary sequence and the gneissic tonalite, and close- to tight-type folds of the schistosity and mylonitic foliation in the Hodge volcanic series; (3) northeast striking, subvertical mylonitic shear zones with low-plunging stretching lineation; and (4) and open folds with subvertical axes of both the gneissic and mylonitic fabric. The structures can be divided based on style and cross-cutting relations into an older gneissic to schistose foliation and tight to isoclinal folds, and younger mylonitic shear zones and open folds.

\section{Planar Fabrics}

Well-defined, northeast trending, subvertical planar fabrics are present in all three areas at Iron Mountain. The fabric

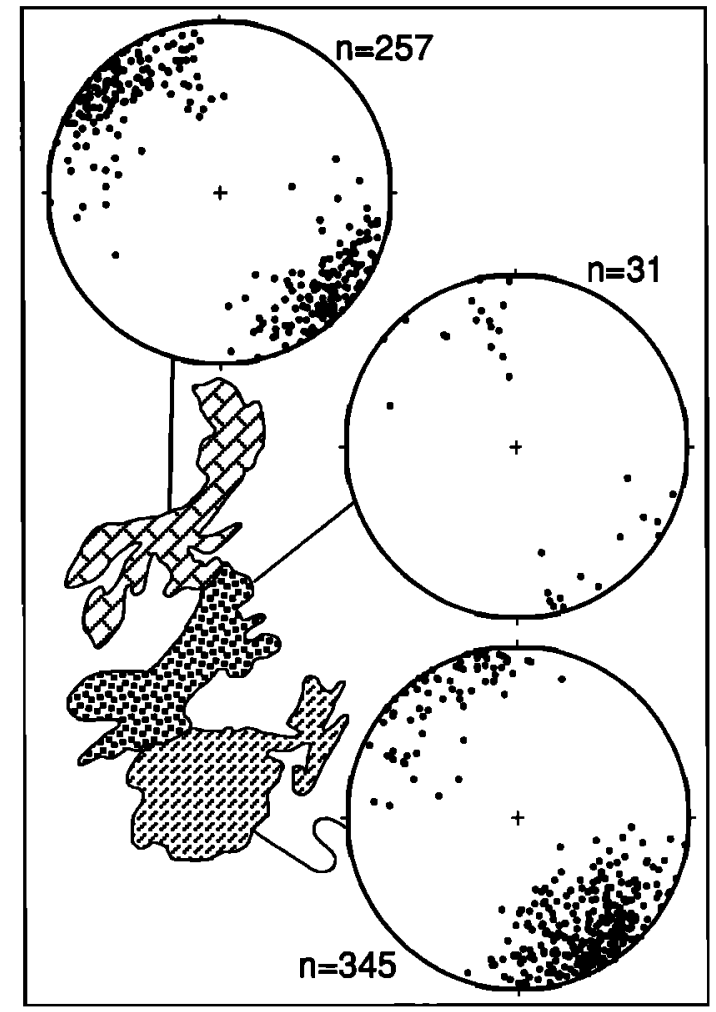

Fig. 5. Poles to foliation in the northern, central and southern areas of Iron Mountain. 
appears as gneissic banding in the tonalite and metasedimentary rocks of the northern area, occurs within L-S tectonites in 0.1 to $10 \mathrm{~m}$ wide mylonitic shear zones in the central plutonic complex and northern intrusive and metasedimentary rocks, and is a pervasive schistosity which becomes mylonitic in the most intensely deformed $\mathbf{S}$ tectonites of the Hodge volcanic series. Poles to foliation planes in the three areas show a fairly wide scatter about a point maximum (Figure 5). Mineral stretching lineations in the ductile shear zones also show a fairly wide scatter and plunge both to the northeast and southwest, typically at low angles (Figure 6). No marked discordance in foliation or lineation orientation occurs between the areas, although the northern area contains a kilometer-scale open fold of the foliation with a continuous change from northeast- to northwest-striking units at the northeastern extreme of the area.

Gneissic and schistose fabric. The tonalite that intrudes the metasedimentary sequence contains two distinct deformation fabrics in outcrop and thin section scale: a crystalloblastic gneissic banding/schistosity and a mylonitic foliation and associated stretching lineation. The gneissic fabric in the tonalite occurs as $1 \mathrm{~mm}$ to $5 \mathrm{~cm}$ thick bands of biotitedominated melanocratic layers and plagioclase- and quartzdominated leucocratic layers. Locally, where coarse-grained biotite is abundant, the fabric is better termed a schistosity. Quartz crystals in the gneissic rocks do not show evidence of grain size reduction and exhibit only weak undulatory extinction. The compositional layering in the metasedimentary sequence defines a gneissic banding that is likely a product of transposed original bedding, as discussed earlier.

The Hodge volcanic series possesses a penetrative schistosity defined by the planar orientation of biotite, white

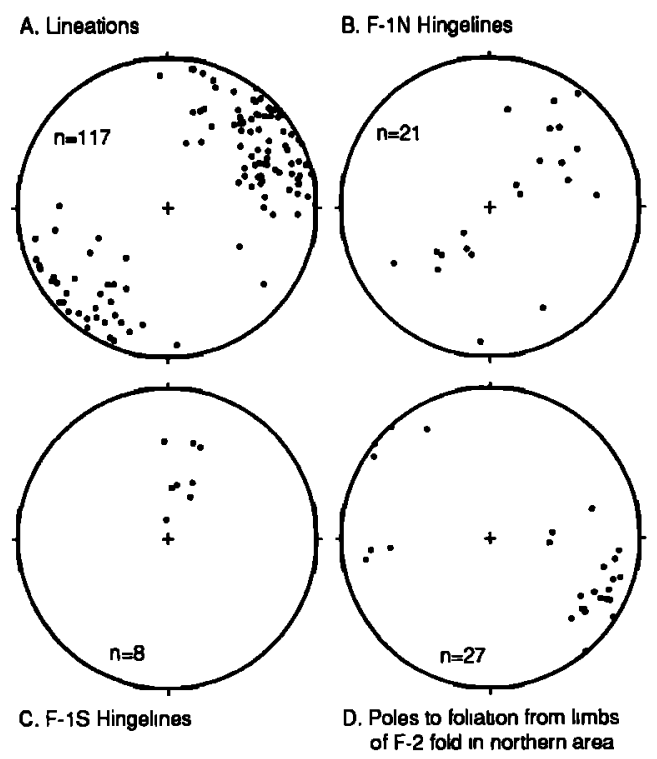

Fig. 6. (a) Trend and plunge of stretching lineation in the northern, central, and southem areas of Iron Mountain. (b) Trend and plunge of hingelines of $F_{1 N}$ folds (folds of the compositional layering in the metasedimentary sequence and gneissic tonalite in the northern area). (c) Trend and plunge of hingelines of $F_{1 S}$ folds (folds of the schistosity and mylonitic fabric in the southem area). (d) Poles to foliation from units on limbs of kilometer-scale, open, upright $F_{2}$ fold in extreme northern part of northern area. Measurements on northwest trending limb are sparse due to poor exposure.

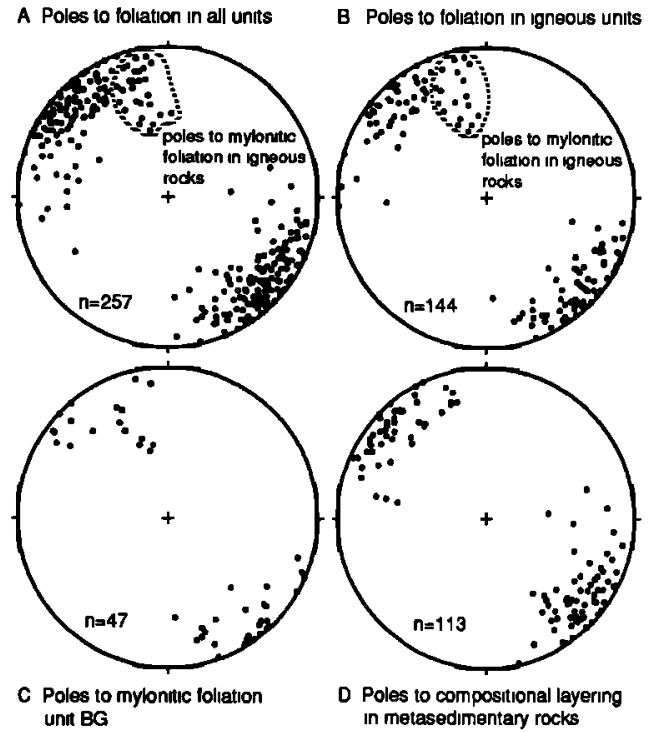

Fig. 7. Poles to foliation in selected units of the northern area. (a) Poles to foliation in all units in the northern area. (b) Poles to foliation in igneous rocks in the northem area; concentration of poles with more northeasterly trend and shallower dip is from mylonitic foliation in sheared peraluminous granite (map unit bg) and sheared biotite tonalite (map unit bt). (c) Poles to mylonitic foliation in unit bg in the northem and central areas. (d) Poles to compositional layering in the metasedimentary sequence in the northern area.

mica, and elongate quartz ribbons that becomes mylonitic in the most intense zones of deformation. The fabric is most mylonitic near the contact with the central plutonic complex and weakens considerably to the southeast. The decrease in intensity of fabric is characterized by the gradual change from highly strained quartz in elongate ribbons to large phenocrysts of quartz in a fine-grained matrix in the quartz-plagioclasebiotite metavolcanic rock. Also, plagioclase is deformed in a brittle manner in the mylonitic areas but appears as undeformed phenocrysts toward the southeast. The penetrative nature of the fabric in the Hodge volcanic series reveals that strain was distributed broadly across the southem area.

Mylonitic shear zones. The deformation characteristics associated with the gneissic banding contrast sharply with those of the mylonitic tonalite, biotite granite and homblende diorite. The most obvious distinction between the mylonitic fabric and the gneissic fabric is the amount of strain in quartz crystals. In the mylonitic rocks, elongate quartz ribbons show both dynamic recovery and dynamic recrystallization. The quartz grains are typically small, show uniform extinction, and have sharp polygonal boundaries but can also show welldeveloped subgrains separated by low-angle boundaries. Furthermore, plagioclase feldspar porphyroclasts are commonly broken and boudinaged in the shear zones, but not in the areas showing a crystalloblastic fabric.

Lower hemisphere projections of poles to foliation show that foliation in the gneissic rocks is subparallel to the mylonitic foliation, except for a small concentration of poles to the mylonitic foliation that show a more northeasterly trend and a shallower dip (Figure 7).

The degree of mylonitization in the shear zones in the northem and central areas varies considerably. Ultramylonites and mylonites are common along the contact between the northem and central areas and in several discrete bands within 
a large area of protomylonite north of the northem/central contact [Boettcher, 1990b]. A general trend of decreasing intensity of mylonitic fabric from south to north can be distinguished. Shear zones are less common, do not show as strong of a grain size reduction, and are not as continuous in the northernmost igneous body as compared to shear zones farther south in the northern area.

Shear-sense indicators are scarce in all three areas and provide conflicting senses of motion. In total, shear-sense indicators were observed at 16 different localities, with dextral indicators observed 10 times and sinistral indicators 6 times. Only in the central area, where s-c fabric is well developed, are the shear-sense indicators consistent: dextral indicators occur at four localities, whereas no unequivocal sinistral indicators were located. In the northem area, sigma-type porphyroclasts show dextral shear sense at four localities and sinistral shear sense at three localities. Most often, porphyroclasts are equivocal in their sense of shear, possibly due to grain-to-grain interference. In the southern area, s-c fabric observed at two localities shows sinistral shear. However, fold asymmetry indicates dextral shear sense at two other localities.

\section{Folds}

$F_{1 N}$ folds (here defined as first generation folds in the northern area) of the compositional layering in the metasedimentary sequence and gneissic tonalite generally have steeply dipping, northeast trending axial surfaces and moderately plunging hinge lines that trend either northeast or southwest (Figure 6). These folds are commonly symmetric, close- to isoclinal-type [Fleuty, 1964] and occur on a meter scale. No $F_{1 N}$ folds of the mylonitic foliation were identified. Hinge lines of close- to isoclinal-type folds of the gneissic

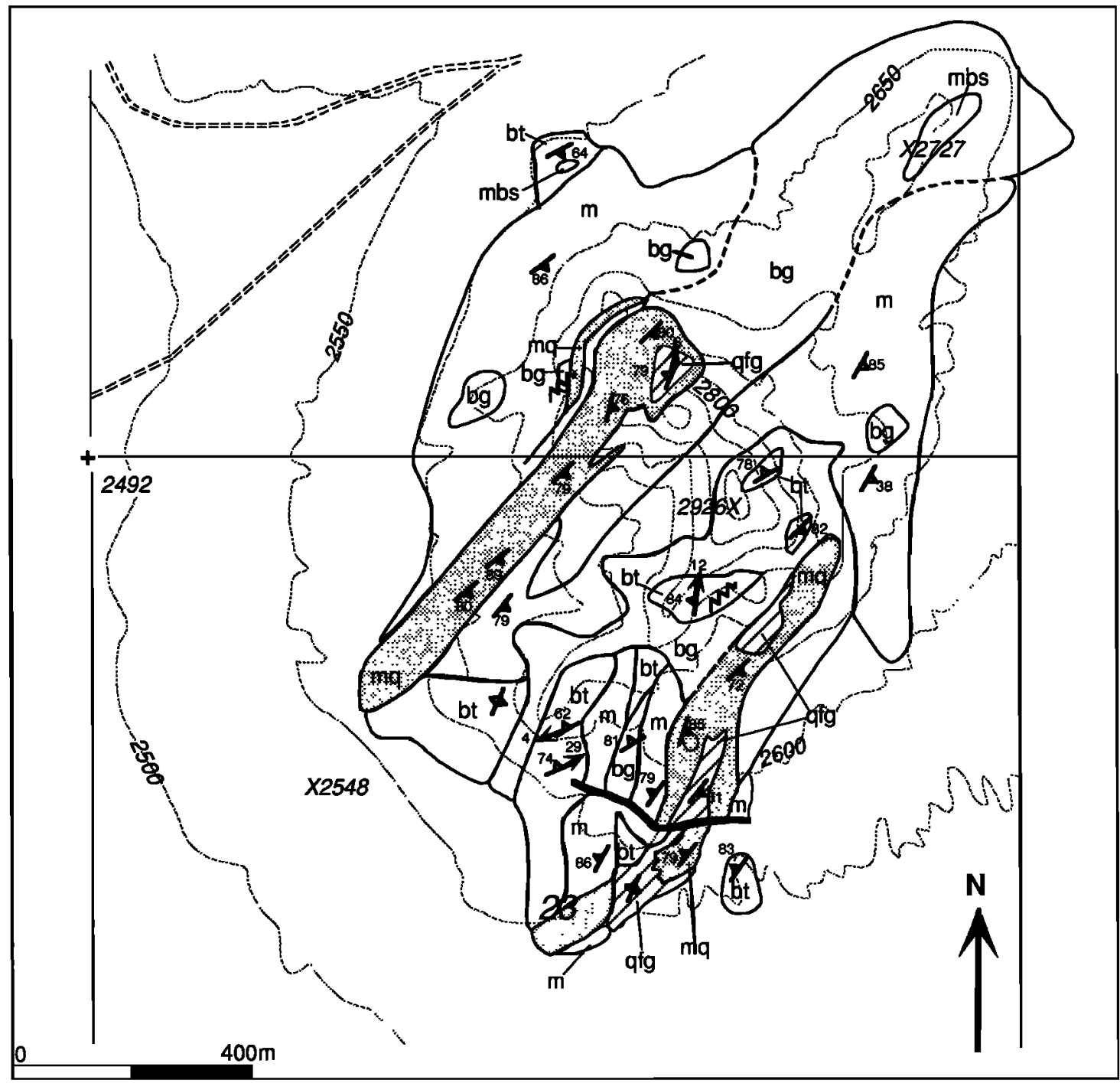

Fig. 8. Geologic map of part of the northern area of Iron Mountain. Note the repetition of the map unit $\mathrm{mq}$. Facing indicators have not been identified in these units, but the dip directions of the units and presence of numerous smaller scale folds with northeast trending, steeply inclined axial planes suggest that a synformal fold is present (mapping by S.S. Boettcher, [1990b]). 


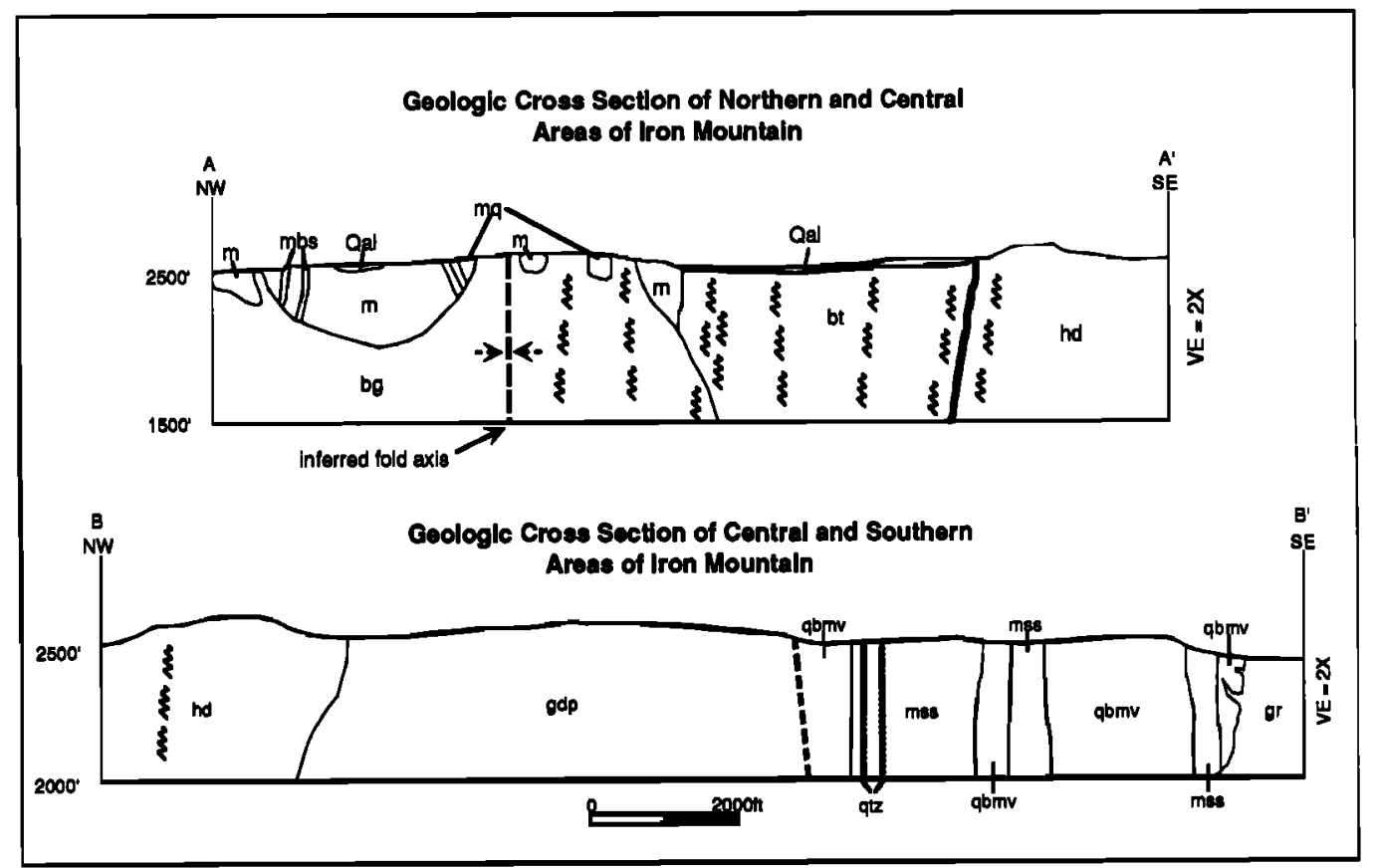

Explanation for geologlc map (Flg. 8) and cross sectlons (Flg. 9)

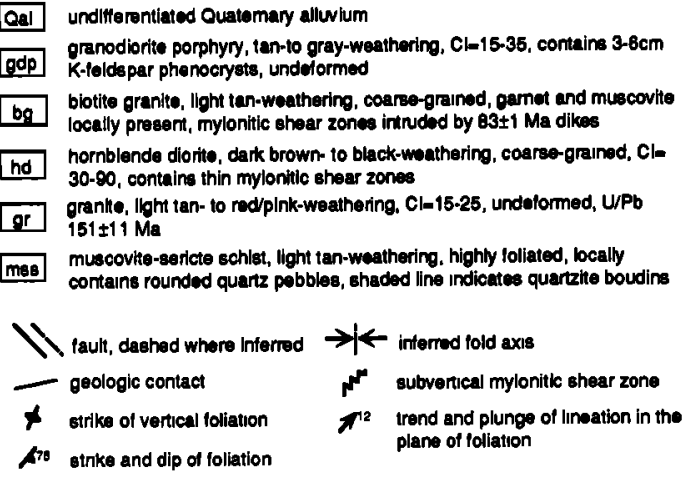

Fig. 9. Geologic cross sections of northern, central and southern areas of Iron Mountain; section lines shown in Figure 3. The contact between the northern area and central area occurs between map units bt and hd and is highly sheared. Cross-cutting relationships show that map unit bg is not involved

banding in the northern area $\left(\mathrm{F}_{1 \mathrm{~N}}\right)$ are subparallel to mineral stretching lineations (Figure 6). A large (wavelength of hundreds of meters), tight fold $\left(F_{1 N}\right)$ parallel to the trend of the outcrop scale folds has been inferred for the northern area based on the repetition of distinctive quartzite units and broad bands of marble (Figures 3 and 8 ). The metasedimentary units, gneissic tonalite, and inferred fold in the northern area are now incompletely preserved as a pendant surrounded by intrusions of crosscutting peraluminous granite (Figures 8 and 9).

The southern area contains local folds of the schistosity and mylonitic foliation (here defined as $\mathrm{F}_{1}$ S), showing " $\mathrm{Z}$ " asymmetry and spaced axial planar cleavage. These folds appear as centimeter-scale, close, angular kink folds in chlorite-rich layers of the muscovite-sericite schist and small,

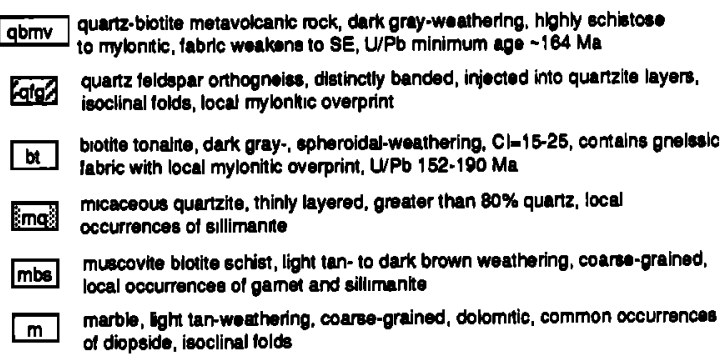

gbrmy quartz-biotite metavolcanic rock, dark gray-weathering, hlghly schiatose to mylontic, tabric waakena to SE, U/Pb minimum age $-164 \mathrm{Ma}$

quartz feldspar orthogneias, distinctly banded, injectod into quartzite layers, isoclinal folds, local mylonkic overprint

blothe tonalte, dark gray-, spheroidal-westhering, $\mathrm{Cl}=15-25$, contains gnelsalc labric with local mylonitic overprint, UPPb $152-190 \mathrm{Ma}$

micaceous quartzite, thinly layered, greater than $80 \%$ quartz, local ing cocurrences of eillimanne

muscovine blotite schist, light tan- to dark brown weathering, coarea-grained, local occurrences of gamet and sillimantte

marble, Lght tan-woathering, coarse-grained, dolomitic, common occurrences of diopside, isoclinal folds

in the inferred fold; this unit does contain mylonitic shear zones. The contact between the central and southern areas occurs between map units gdp and qbmv and is inferred to be faulted. The dip of units is highly variable but is typically subvertical.

close folds with rounded hinges in the quartz-rich layers. $F_{1 S}$ folds have steeply inclined, north striking axial surfaces and moderately plunging, north trending hinge lines (Figure 6).

$F_{1 S}$ folds of the schistosity and mylonitic foliation in the southern area of Iron Mountain are sparse, except for two distinct chlorite-rich and quartz-rich layers within the muscovite-sericite schist unit. Only 20 lineations were measured in the predominantly $S$ tectonites of the Hodge volcanic series, compared with almost 100 in the northem and central areas combined. Additionally, hinge lines of $F_{15}$ folds are poorly exposed, making comparison between hinge line and lineation orientation difficult. On the basis of the few measurements of these structural elements (Figure 6), hinge lines and lineations are oblique to one another in the southem area. Furthermore, axial planes, locally well represented by 
axial planar cleavage, are oblique to the schistose/mylonitic foliation. This differs from axial planes of $F_{1 N}$ folds, which are typically parallel to regional fabric.

All three areas contain gentle to open folds of the foliation $\left(\mathrm{F}_{2}\right)$ about subvertical axes that change the strike of the foliation up to $90^{\circ}$. Both mylonitic and gneissic fabrics are affected by the $F_{2}$ folds. This style of folding is most evident in the eastern end of the northern area where the foliation in all units changes strike from about $\mathrm{N}^{\circ} 0^{\circ} \mathrm{E}$ to $\mathrm{N} 10^{\circ} \mathrm{W}$ (Figures 3 and 6). Dibblee [1968] mapped geometrically similar folds with subvertical axes in two gneissic complexes west of Harper Lake, approximately $15 \mathrm{~km}$ northwest of Iron Mountain.

\section{Brittle Faults}

North to northwest trending strike-slip faults, presumably related to Cenozoic right-lateral faults in the central Mojave Desert (Figure 2), are sparse in all three areas of Iron Mountain. Four map-scale $(1: 12,000)$ faults were observed, with separations limited to tens of meters, commonly in an apparent right-lateral sense. Additionally, modification of the contact between the granodiorite porphyry and the Hodge volcanic series along a high-angle reverse fault with minor offset is suggested by the presence of steeply raking striations on quartzite boudins south of the contact. Steep striations on steeply inclined, north dipping planar surfaces also occur in a few outcrops of felsite dikes and in muscovite-gamet granite dikes in the northern area. These faults involve the youngest igneous phases and may be related to N-S directed Neogene contractile deformation in the central and western Mojave Desert [Bartley et al., 1990].

\section{DEFORMATION HISTORY AND REGIONAL -IMPLICATIONS}

Comparison of metamorphic facies, structure, and lithology with other areas in the Mojave Desert, combined with U-Pb geochronology of four igneous units at Iron Mountain, form the basis for assessment of the timing of structures at Iron Mountain. The relative timing of these structures is crucial to the establishment of a regional tectonic setting. Figure 10 is a summary of Permian to Paleocene deformation, plutonism, volcanism, and sedimentation across the central Mojave Desert.

\section{Early Mesozoic Extension}

No structural evidence for early Mesozoic extension was found at Iron Mountain. However, the Hodge volcanic series contains layers of orthoquartzite and muscovite-sericite schist

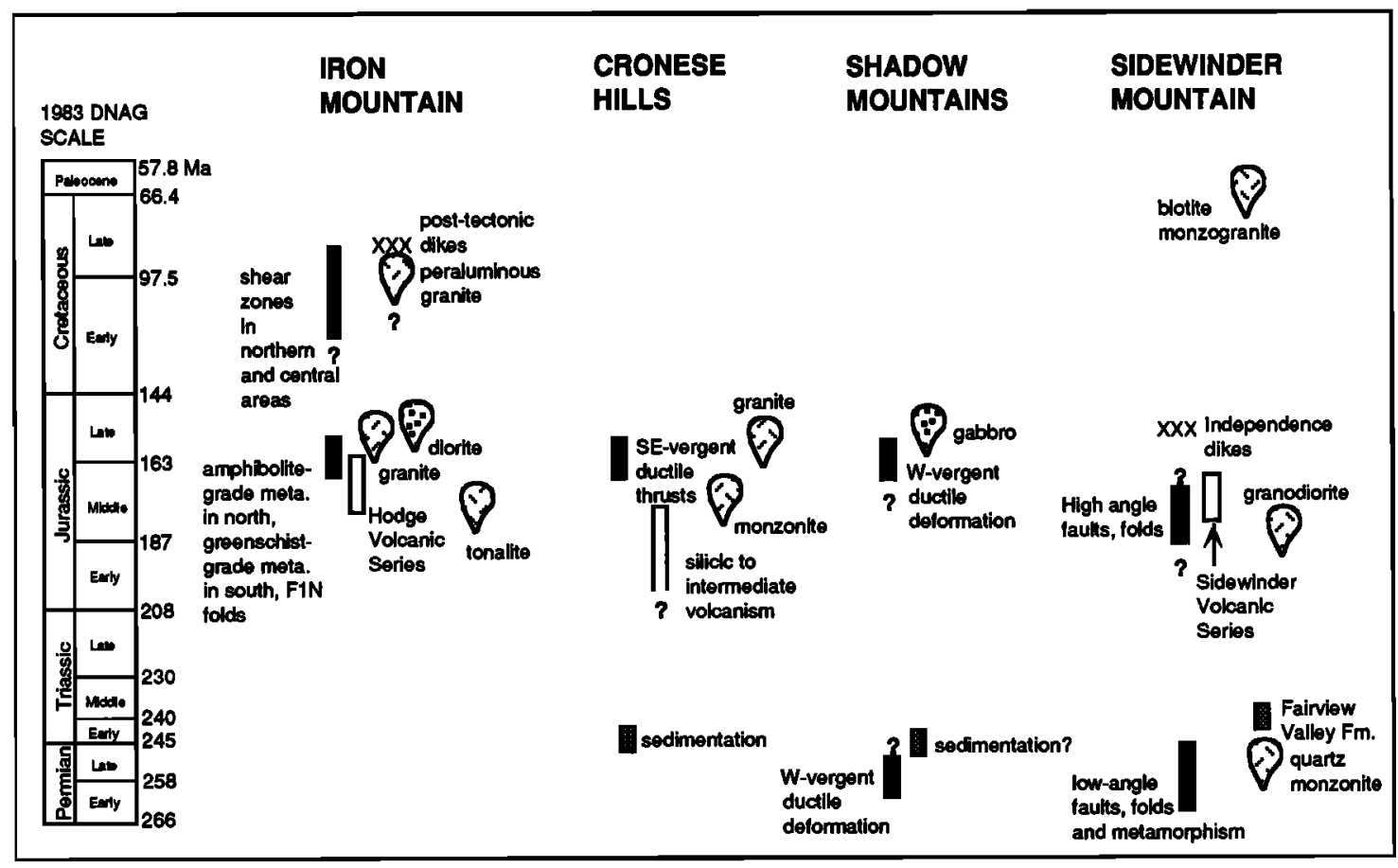

Fig. 10. Comparison of deformation histories across the central Mojave Desert. Cronese Hills data from Walker et al. [1990]; Shadow Mountains data from Martin et al. [1990]; Sidewinder Mountain data from Karish et al. [1987] and E. Miller [1981]; 1983 DNAG time scale from Palmer [1983]. Designation of shear zones in the northern and central areas as Cretaceous is dependent on the age of the sheared peraluminous granite in the northem area. The shear zones are younger than the sheared hornblende diorite, which is probably $148 \mathrm{Ma}$, and older than undeformed, northwest trending dikes of $83 \pm 1$ Ma muscovite-garnet granite (U-Pb on monazite, Boettcher and Walker, [1990]). Gneissic fabric, $F_{1 N}$ folds, and amphibolite facies metamorphism in the northern area are considered coeval with highly schistose and locally mylonitic fabric and greenschist facies metamorphism in the southern area on the basis that this deformation occurred before the intrusion of $148 \mathrm{Ma}$ ? hornblende diorite and 151 Ma granite, but after the intrusion of Jurassic gneissic tonalite and extrusion of Jurassic Hodge volcanic series. 
with quartz pebbles that elsewhere have been interpreted as accumulating in extensional basins along the early Mesozoic volcano-plutonic arc [Busby-Spera, 1988]. Late Triassic(?) to Middle Jurassic volcanic and sedimentary rocks in the central Mojave Desert occur in a roughly E-W trending band from Quartzite Mountain to the Rodman Mountains. Volcanic rocks of this age are also common in the northeastern Mojave Desert [Burchfiel and Davis, 1981]. An alternative hypothesis to extension along the arc involves cycles of intermittent volcanism followed by erosion and redeposition of the volcanic sequence with periodic burial by eolian[?] quartz sand.

\section{Jurassic Contractional Deformation}

Walker et al. [1990a] have proposed that the east Sierran contractile belt [Dunne, 1986, Figure 1] is expressed as southeast to west vergent structures that occur in a belt from the Cronese Hills (50 km northeast of Barstow, California) to the Shadow Mountains ( $30 \mathrm{~km}$ southwest of Barstow, California) (Figure 2). In the Cronese Hills, a ductile shear zone with several kilometers of offset, greenschist facies metamorphism, and macroscopic isoclinal folds formed between 169-154 Ma, based on dates on pretectonic and posttectonic plutons [Walker et al., 1990a]. In the Shadow Mountains, a macroscopic, west vergent, recumbent anticline, schistose fabric and transposed compositional layering formed prior to the intrusion of an undeformed $148 \mathrm{Ma}$ gabbro complex [Martin and Walker, 1990, 1991].

Penetrative deformation in the southern area of Iron Mountain occurred between $\sim 164 \mathrm{Ma}$ and $151 \pm 11 \mathrm{Ma}$. Roughly equivalent deformation in the northern area of Iron Mountain occurred before the intrusion of Late Jurassic homblende diorite and after the intrusion of Jurassic gneissic tonalite (probably between 170 and $148 \mathrm{Ma}$ ). Direct evidence for ductile thrust faults at Iron Mountain is absent, but $F_{1 N}$ folds are probably similar in age to deformation in the Cronese Hills and Shadow Mountains. The decrease in grain size reduction toward the southeast in the Hodge volcanic series and the decrease in metamorphic grade from north to south leaves open the possibility that the metasedimentary sequence was thrust over the Hodge volcanic series before the intrusion and shearing of the central plutonic complex.

Kiser [1981] reported sillimanite + K-feldspar assemblages and quartz + hornblende + garnet + plagioclase assemblages in metasedimentary rocks of the Hinkley Hills. This suggests that regional metamorphism affected both the Hinkley Hills and the northern area of Iron Mountain prior to the intrusion of the Mesozoic gabbro complex, which is distinctly metamorphosed only in the mylonitic shear zones. The presence of K-feldspar in metasedimentary rocks of the Hinkley Hills suggests that temperatures were higher there than at Iron Mountain, where muscovite appears as a stable phase in the amphibolite facies assemblage. The presence of kinked and folded biotite and sillimanite at Iron Mountain suggests that Jurassic deformation may have outlasted peak metamorphic conditions.

\section{Cretaceous Deformation}

Field evidence reveals that the mylonitic shear zones in the northern and central areas originated after the intrusion of Late Cretaceous(?) peraluminous granite, but before the intrusion of $83 \pm 1 \mathrm{Ma}$, northwest trending, peraluminous granite dikes. Ultramylonite along the contact between the central and northern areas and the linear nature of this contact are of tectonic origin. Both hornblende diorite and tonalite show a high degree of grain size reduction and thinly spaced planar layers on either side of the contact. Dikes of biotite granite that intrude the hornblende diorite in the central area are also mylonitic, with subparallel orientations to other mylonites in the area, indicating that tectonic modification of the contact between the northern and central areas occurred after the intrusion of the biotite granite dikes into the diorite complex. The gabbro dikes, biotite granite dikes, and the leucocratic biotite granite cross-cut the transposed compositional layering in the metasedimentary sequence and do not contain tight to isoclinal folds. The absence of distributed amphibolite or greenschist facies mineral assemblages outside of the mylonitic shear zones in the biotite granite and hornblende diorite indicates that the intrusion of these units occurred after regional metamorphism of the northern and southem areas. Therefore we conclude that they were intruded and deformed following the initial deformation of the gneissic tonalite, injection gneiss, and metasedimentary units.

Cretaceous regional deformation is not documented in the central Mojave Desert but is well documented in the Old Woman and Piute Mountains [C.F. Miller et al., 1982; Fletcher and Karlstrom, 1990] in the eastern Mojave Desert, in the Maria fold and thrust belt in western Arizona [Laubach et al., 1989], in the Rand Mountains [Jacobson, 1990] and at Fremont Peak [J.S. Miller et al., 1992] in the northeastem Mojave Desert , and at Cajon Pass north of the San Andreas Fault [Ehlig, 1988; Silver et al., 1988].

\section{Eugeoclinal/Miogeoclinal Boundary}

Investigation of metasedimentary rocks at Iron Mountain provides new data on the location of the eugeoclinal/miogeoclinal boundary in the central Mojave Desert. Allochthonous eugeoclinal rocks in the northwestern Mojave Desert are thought to have been transported south from the Antler flysch belt along the truncated margin of the Cordilleran miogeocline during the late Paleozoic [Burchfiel and Davis, 1975, 1981; Davis et al., 1978; Walker, 1988]. Alternatively, Snow [1992] has proposed that eugeoclinal rocks are carried in the hanging wall of the Permian Last Chance thrust system. Eugeoclinal rocks have been identified in the Goldstone area [Miller and Sutter, 1982], in the Paradise Range [Wust, 1981] and at Lane Mountain [McCulloh, 1952]. Miogeoclinal rocks have been identified in the Victorville area [Stewart and Poole, 1975; Miller, 1977, 1981a, b], in the Hinkley Hills [Kiser, 1981], and in the Shadow Mountains [Martin and Walker, 1990, 1991] (Figure 2). The large proportion of marble and quartzite relative to calc-silicate rocks and pelitic schists at Iron Mountain suggests that the metasedimentary sequence there was deposited in a miogeoclinal or craton margin setting [Boettcher, 1990b]. The tectonic boundary between eugeoclinal and miogeoclinal rocks thus lies to the north and west of Iron Mountain.

\section{Central Mojave Metamorphic Core Complex}

Finally, Walker et al. [1990b] have described Iron Mountain as possibly lying in the footwall of the central Mojave metamorphic core complex. Mylonitic fabrics at Iron Mountain are no younger than $83 \pm 1 \mathrm{Ma}$, northwest trending, muscovite-garnet granite dikes and, therefore, are unrelated to Early Miocene extension in the central Mojave Desert. Highangle normal faults and Tertiary strata, common to hanging wall blocks elsewhere in the central Mojave Desert, are absent at Iron Mountain. The lack of Tertiary extensional features at Iron Mountain, and elsewhere in the western Mojave Desert [Bartley et al., 1990], suggests that Iron Mountain is located west of the area of Tertiary extension in the central Mojave Desert. If so, the breakaway zone for Tertiary detachment 
faults in the central Mojave Desert, prior to late Cenozoic erosion, is located east of Iron Mountain and west of the westernmost known exposures of Tertiary mylonitic rocks in the Hinkley Hills and Harper Dry Lake.

Results from reconnaissance thermochronologic studies at Iron Mountain are compatible with the interpretation that Iron Mountain lies west of the main zone of Tertiary extension in the central Mojave Desert. Specifically, biotite ${ }^{40} \mathrm{Ar}-{ }^{39} \mathrm{Ar}$ and sphene, zircon, and apatite fission track analyses suggest that Iron Mountain cooled slowly from greater than $\sim 300^{\circ} \mathrm{C}$ at $\sim 65 \mathrm{Ma}$ to less than $\sim 100^{\circ} \mathrm{C}$ by $\sim 30 \mathrm{Ma}$ [Dokka et al., 1991; Jones et al., 1990]. Thus, no significant tectonic unroofing occurred at Iron Mountain during the period of maximum extension (22-20 Ma) in the central Mojave Desert.

\section{CONCLUSIONS}

Metasedimentary rocks in the northern area of Iron Mountain are probably miogeoclinal in character and are related to passive margin sedimentation along the continental margin of western North America during Late Precambrian to early Paleozoic time. The metasedimentary sequence in the northern area likely predates the Wood Canyon Formation and is similar to a sequence of dominantly dolomitic marble with lesser amounts of calc-silicate and quartzite at Quartzite Mountain, near Victorville. The presence of miogeoclinal rocks at Iron Mountain indicates that the eugeoclinal/ miogeoclinal boundary in the central Mojave Desert and the proposed Cretaceous Mojave-Snow Lake fault must pass north and west of Iron Mountain.

Penetrative deformation in the northern and southem areas of Iron Mountain produced greenschist to amphibolite facies metamorphism, transposition of compositional layering, centimeter- to meter-scale close- to isoclinal-type folds, and an inferred kilometer-scale isoclinal fold. U-Pb geochronology on posttectonic granite and the Hodge volcanic series along with regional correlation of the Hodge volcanic series with the Sidewinder volcanic series constrains deformation in the southem area to the interval 151-164 Ma. Deformation in the northem area of Iron Mountain occurred before the intrusion of Late Jurassic homblende diorite (148 Ma?) and after the intrusion of Middle (?) Jurassic gneissic tonalite (170 Ma?). This deformation is interpreted to lie in a belt of Middle to Late Jurassic contractile deformation that runs northeastward across the Mojave Desert and forms the continuation of the east Sierran contractile belt.

A second episode of deformation at Iron Mountain produced 0.1 to $10 \mathrm{~m}$ wide, subvertical mylonitic shear zones and greenschist facies metamorphism in the northern and central areas. U-Pb geochronology on posttectonic dikes and assignment of deformed peraluminous granite to the 80-110 Ma period of Sierran magmatism constrains this deformation to the interval 83-110 Ma.

Finally, evidence for Tertiary extension is absent at Iron Mountain, possibly indicating that Iron Mountain lies southwest of the breakaway zone for the central Mojave metamorphic core complex.

Acknowledgments. Financial support during field study was provided by a MacCarthy Fellowship from the University of North Carolina at Chapel Hill and graduate student research awards from the Geological Society of America-Southeastern Section and Sigma Xi. Additionally, National Science Foundation grants EAR-8817076 and EAR-8917291 awarded to A.F. Glazner and EAR-8816628 and EAR-8916802 awarded to Walker supported this project. A.F. Glazner is particularly thanked for initiating this study, sharing ideas in the field, and for significant comments on the manuscript. Reviews of the manuscript by K.G. Stewart, J.R. Butler, and $M$. Cloos greatly improved the final products of this project. Additional reviews by $P$. Stone and an anonymous reviewer helped to consolidate and focus the manuscript. Discussions with J.M. Bartley, M.W. Martin and J.M. Fletcher aided in establishing a regional context. Field assistance and suggestions from J.A. Roska and J.S. Miller were invaluable to this project.

\section{REFERENCES}

Bartley, J.M., A.F. Glazner, and E.R.

Schermer, North-south contraction of the Mojave block and strike-slip tectonics in southern California, Science, 248, 1398 $1401,1990$.

Boettcher, S.S., Structure of sheared Mesozoic rocks at Iron Mountain, central Mojave Desert, California, Geol. Soc. Am. Abstr. Programs, 22, A9, 1990a.

Boettcher, S.S., Structure and petrology of Iron Mountain, central Mojave Desert, California, M.S. thesis, University of North Carolina at Chapel Hill, 94 pp., 1990 b.

Boettcher, S.S., and J.D. Walker, Mesozoic deformation at Iron Mountain, central Mojave Desert, Califomia, Geol. Soc. Am. Abstr. Programs, 22, A275, 1990.

Bowen, O.E., Jr., Geology and mineral deposits of the Barstow Quadrangle, Bulletin Calif. Div. of Mines Geol., 165, 7$185,1954$.

Burchfiel, B.C, and G.A. Davis, Nature and controls of Cordillera orogenesis, western United States: Extensions of an earlier synthesis: Am.J.Sci., 275A, 363-395, 1975

Burchfiel, B.C., and G.A. Davis, Mojave Desert and environs, in The Geotectonic Development of California, Rubey Symp. vol. 1, edited by W.G. Ernst, pp. 217-252,
Prentice Hall, Englewood Cliffs, N.J., 1981.

Busby-Spera, C.J., Speculative tectonic model for the early Mesozoic arc of the southwest Cordilleran United States, Geology, 16, 1121-1125, 1988.

Busby-Spera, C.J., J.M. Mattinson, N.R. Riggs, and E.R. Schermer, The TriassicJurassic magmatic arc in the MojaveSonoran Deserts and the Sierran-Klamath region: Similarities and differences in paleogeographic evolution, in Paleozoic and Early Mesozoic Paleogeographic Relations: Sierra Nevada, Klamath Mountains, and Related Terranes, edited by D.S. Harwood, and M.M. Miller, Boulder, Colorado, Geol. Soc. Am. Spec. Pap., 225, pp. 325-337, 1990.

Cameron, C.S., Stratigraphy and significance of the upper Precambrian Big Bear Group, in Geology of Selected Areas in the San Bernardino Mountains, Western Mojave Desert, and Southern Great Basin, California, edited by J.P. Cooper, B.W. Troxel, and L.W. Wright, pp. 5-20, $78^{\text {th }}$ Annual Meeting of the Cordilleran Section, Geological Society of America, Fresno, Calif., 1982.

Chen, J.H., and J.G. Moore, Uranium-lead isotopic ages from the Sierra Nevada batholith, California, J. Geophys. Res., 87, 4761-4784, 1982.

Davis, G.A., J.W.H. Monger, and B.C. Burchfiel, Mesozoic construction of the Cordilleran "collage" central British Colombia to central California, in Mesozoic Paleogeography of the Western United States, edited by D.G. Howell, and K.A. McDougall, vol. 2, pp. 1-32, Society of Economic Paleontologists and Mineralogists, Tulsa, Okla., 1978.

Dibblee, T.W., Preliminary geologic map of the Barstow quadrangle, California US. Geol. Surv. Mineral Invest. Field Stud. Map MF-229, 1960.

Dibblee, T.W., Areal geology of the western Mojave Desert, Califomia, US. Geol. Surv. Prof. Pap. 522, 153 pp., 1967.

Dibblee, T.W., Geology of the Fremont Peak and Opal Mountain quadrangles, California, Bullet in Calif. Div. of Mines Geol., 188, 64 pp., 1968.

Dokka, R.K., D.J. Henry, T.M. Ross, A.K. Baksi, J. Lambert, C.J. Travis, S.M. Jones, C. Jacobsen, M.M. McCurry, M.O. Woodburne, J.P. Ford, Aspects of the Mesozoic and Cenozoic geologic evolution of the Mojave Desert, Guidebook for the 1991 Annual Meeting of the Geological Society of America, pp. 1-43, Geological 
Society of America, San Diego, Calif., 1991.

Dunne, G.C., Geologic evolution of the southern Inyo Range, Darwin Plateau, and Argus and Slate Ranges, east-central California: An overview, Geological Society of America Cordilleran Section Field Trip Guidebook, pp. 3-21, Geological Society of America, Los Angeles, 1986.

Dunne, G.C., and J.D. Walker, New age constraints on Jurassic volcanism and tectonism, southern Owens Valley area, east-central California, Geol. Soc. Am. Abstr. Programs, 23, A248-A249, 1991.

Dunne, G.C., R.M. Gulliver, and A.G. Sylvester, Mesozoic evolution of rocks of the White, Inyo, Argus and Slate Ranges, eastern California, in Mesozoic Paleogeography of the Western United States, edited by D.G. Howell, and K.A. McDougall, vol. 2, pp. 189-208, Society of Economic Paleontologists and Mineralogists, Tulsa, Okla.,1978.

Ehlig, P.C., Character of basement rocks exposed near the Cajon Pass scientific drill hole, Geophys. Res. Lett., 15, 949-952, 1988

Fletcher, J.M., and K.E. Karlstrom, Late Cretaceous ductile deformation, metamorphism and plutonism in the Piute Mountains, eastern Mojave Desert, $J$. Geophys. Res., 95, 487-500, 1990.

Fleuty, M.J., The description of folds, Proc. Geol. Assoc. London, 75, 461-492, 1964.

Glazner, A.F., J.D. Walker, J.M. Bartley, and S.B. Dent, Distribution and relations of Precambrian and Paleozoic rocks in the central Mojave Desert, California, Geol. Soc. Am. Abstr. Programs, 20, 163, 1988.

Graubard, C.M., J.M. Mattinson, and C.J. Busby-Spera, Age of the lower Sidewinder volcanics and reconstruction of the early Mesozoic arc in the Mojave Desert, Geol. Soc. Am. Abstr. Programs, 20, A274, 1988.

Hazzard, J.C., Paleozoic section in the Nopah and Resting Springs Mountains, Inyo County, California, Calif. J. Mines Geol. 33, 273-339, 1937.

Jacobson, C.E., The ${ }^{40} \mathrm{Ar} /{ }^{39} \mathrm{Ar}$ geochronology of the Pelona Schist and related rocks, southem California, $J$. Geophys. Res., 95, 509-528, 1990.

Jennings, C.W. (compiler), Geologic map of California, Calif. Geol. Data Map Ser., map 2, scale 1:750,000, Calif. Div. Mines and Geol., 1977.

Jones, S.M., A.K. Baksi, and R.K. Dokka, Cooling histories of upper and lower plate rocks in metamorphic core complexes of the Mojave Extensional Belt, California, Geol. Soc. Am. Abstr. Programs, 22, A33, 1990.

Karish, C.R., E.L., Miller, and J.F. Sutuer, Mesozoic tectonic and magmatic history of the central Mojave Desert, in Mesozoic rocks of southem Arizona and adjacent regions, edited by W. Dickinson, and $\mathrm{M}$. Klute, Ariz. Geol. Soc. Dig., 18, 15-32, 1987.

Kiser, N.L., Stratigraphy, structure and metamorphism in the Hinkley Hills, Barstow, Califomia, M.S. thesis, 70 pp., Stanford University, Palo Alto, Calif., 1981.

Krogh, T.E., A low-contamination method for hydrothermal decomposition of zircon and extraction of $\mathrm{U}$ and $\mathrm{Pb}$ for isotopic age determinations, Geochim. Cosmochim. Acta, 37, 485-494, 1973.

Krogh, T.E., Improved accuracy of U-P. $b$ zircon ages by the creation of more concordant systems using an air abrasion technique, Geochim. Cosmochim. Acta, 46, 637-649, 1982.

Lahren, M.M., R.A. Schweickert, J.M. Mattinson, and J.D. Walker, Evidence of uppermost Proterozoic to Lower Cambrian miogeoclinal rocks and the Mojave-Snow Lake fault: Snow-Lake pendant, Central Sierra Nevada, California, Tectonics, 9, 1585-1608, 1990.

Laubach, S.E., S.J. Reynolds, J.E. Spencer, and S. Marshak, Progressive deformation and superposed fabrics related to Cretaceous crustal underthrusting in westem Arizona, U.S.A., J. Struct. Geol. 11, 735-749, 1989.

Ludwig, K.R., Plotting and regression programs for isotope geochemists for use with HP-86/87 microcomputers, U.S. Geol. Surv. Open File Rep. 83-849, 94 pp., 1983.

Martin, M.W., and J.D. Walker, New stratigraphic and structural relationships from the Shadow Mountains, western Mojave Desert, Geol. Soc. Am. Abstr. Programs, 21, 268, 1989.

Martin, M.W., and J.D. Walker, New stratigraphic relationships from the Shadow Mountains, western Mojave Desert: Implications for late Paleozoic paleogeography, Geol. Soc. Am. Abstr. Programs, 22, 64, 1990.

Martin, M.W., and J.D. Walker, Upper Precambrian to Paleozoic paleogeographic reconstruction of the Mojave Desert, California, in Paleozoic Paleogeography of the Western United States-II, edited by J.D. Cooper, and L.H. Stevens, Society of Economic Paleontologists and Mineralogists, vol. 67, pp. 167-192, Tulsa, Okla. 1991.

McCulloh, T.H., Geology of the southem half of the Lane Mountain quadrangle, California, Ph.D dissertation, 180 pp. Univ. of Calif., Los Angeles, Calif., 1952.

Miller, C.F., K.A. Howard, and T.D. Hoisch, Mesozoic thrusting, metamorphism, and plutonism, Old Woman-Piute Range, southeastern California, in MesozoicCenozoic Tectonic Evolution of the Colorado River Region, California. Arizona, and Nevada, edited by E.G. Frost. and D.L. Martin, Geological Society of America, pp. 561-582, 1982.

Miller, E.L., Geology of the Victorville region, California, $\mathrm{Ph}$.D. dissertation, 226 pp., Rice University, Houston, Texas, 1977.

Miller, E.L., Geology of the Victorville region, Califomia, Part I, Geol. Soc. Am. Bull., 92, 160-163, 1981a.

Miller, E.L., Geology of the Victorville region, California, Part II, Geol. Soc. Am. Bull. 92, 554-608, 1981b.

Miller, E.L., and J.F. Sutter, Structural geology and ${ }^{40} \mathrm{Ar} /{ }^{39} \mathrm{Ar}$ geochronology of the Goldstone-Lane Mountain area, Mojave Desert, Califomia, Geol. Soc. Am. Bull., 93, 1191-1207, 1982.

Miller, J.S., J.M. Fletcher, S.S. Boettcher, M.W. Martin, A.F. Glazner, and UNC Advanced Field Camp, Late Cretaceous deformation, plutonism, and cooling around Fremont Peak, central Mojave
Desert, California, EOS, 73, 574, 1992.

Miller, W.J., Geology of parts of the Barstow Quadrangle, San Bernardino County, California, Calif. J. Mines and Geol., 73$112,1944$.

Palmer, A.R., (compiler), The decade of North American geology 1983 geologic time scale, Geology, 11, 503-504, 1983.

Parrish, R.R., An improved micro-capsule for zircon dissolution and $\mathrm{U}-\mathrm{Pb}$ geochronology, Isotope Geosci., 66, 99$102,1987$.

Parrish, R.R., U-Pb dating of monazite and its application to geologic problems, Can.J. Earth Sci., 27, 1431-1450, 1990.

Silver, L.T., E.W. James, and B.W. Chappel, Petrological and geochemical investigations at the Cajon Pass deep drillhole, Geophys. Res. Lett., 15, 961-964, 1988.

Snow, J.K., Large magnitude Permian shortening and continental margin tectonics in the southern Cordilerra, Geol. Soc. Am. Bull., 104, 80-105, 1992.

Stacey, J.S., and J.D. Kramers, Approximation of terrestrial lead isotope evolution by a two-stage model, Earth Planet. Sci. Lett., 26, 207-221, 1975.

Steiger, R.H., and E. Jäger, Subcommission on geochronology: Convention on the use of decay constants in geo- and cosmochronology, Earth Planet. Sci. Lett. 36, 359-362, 1977.

Stewart, J.H., Upper Precambrian and Lower Cambrian strata in the southern Great Basin, California and Nevada, U.S. Geol. Surv. Prof. Pap. 620, 206 pp., 1970.

Stewart, J.H., and F.G. Poole, Extension of the Cordilleran miogeosynclinal beit to the San Andreas Fault, southern California, Geol. Soc. Am. Bull., 86, 205-212, 1975.

Walker, J.D., Permian and Triassic rocks of the Mojave Desert and their implications for the timing and mechanism of continental truncation, Tectonics, 7, 685 709, 1988.

Walker, J.D., M.W. Martin, J.M. Bartley, and D.S. Coleman, Timing and kinematics of deformation in the Cronese Hills, California, and implications for Mesozoic structure of the southwest Cordillera Geology, 18, 554-557, 1990a.

Walker, J.D., J.M. Bartley, and A.F. Glazner, Large-magnitude Miocene extension in the central Mojave Desert: Implications for Paleozoic to Tertiary paleogeography and tectonics, J. Geophys. Res., 95, 557-569. 1990b.

Walker, J.D., M.W. Martin, J.M. Bartley, and A.F. Glazner, Middle to Late Jurassic deformation belt through the Mojave Desert, Geol. Soc. Am. Abstr. Programs, $22,91,1990$ c.

Winkler, H.G.F., Petrogenesis of metamorphic rocks, 348 pp., SpringerVerlag, New York, 1979.

Wust, S.L., Geology and structure of the Paradise Range, San Bernardino County, California M.S. thesis, 69 pp., Stanford University, Stanford, Calif., 1981.

S. S. Boettcher, Department of Geological Sciences, University of Texas at Austin, Austin. TX 78712

J.D. Walker, Department of Geology, University of Kansas, Lawrence, KS 66045-2124.

Received February 10, 1992

revised September 16, 1992:

accepted October 9, 1992.) 